\title{
Beauty food activities of extracts from Pinus densiflora root
}

\author{
Eun-Ho Lee ${ }^{1} \cdot$ Ki-Tae Park ${ }^{2} \cdot$ Hye-Jin Park ${ }^{1}$ (D) $\cdot$ Jae-Bum Jo $^{1} \cdot$ Jae-Eun Lee $^{1}$. \\ Su-Bin Lim ${ }^{1}$ - Ye-Jin Kim ${ }^{1}$ Dong-Hyun $\mathrm{Ahn}^{3}$ - Young-Je Cho ${ }^{1}$ (D)
}

\section{동송근(Pinus densiflora root) 추출물의 미용식품활성}

\author{
이은호 ${ }^{1} \cdot$ 박기태 $^{2} \cdot$ 박혜진 $^{1}$ - 조재범 ${ }^{1}$ - 이재 은 $^{1} \cdot$ 임수빈 $^{1} \cdot$ 김예진 $^{1}$ • \\ 안동현 $^{3} \cdot$ 조영제 ${ }^{1}$
}

Received: 3 March 2017 / Accepted: 30 March 2017 / Published Online: 30 June 2017

(C) The Korean Society for Applied Biological Chemistry 2017

\begin{abstract}
The extracted phenolic compounds from Pinus densiflora root were examined biological activities for beauty food. The tyrosinase inhibitory activity which was related to skin-whitening was observed. The tyrosinase inhibitory activity was confirmed to be $92 \%$ in ethanol extract at $50 \mu \mathrm{g} / \mathrm{mL}$ phenolic. The elastase and collagenase inhibitory activity as anti-wrinkle effect were showed 61 and $78 \%$ in ethanol extract at $200 \mu \mathrm{g} / \mathrm{mL}$ phenolic, respectively. Astringent effect of ethanol extract was showed to be $82 \%$ at 50 $\mu \mathrm{g} / \mathrm{mL}$ phenolic. Hyaluronidase inhibitory activity of ethanol extract as anti-inflammation effect was confirmed to be $94 \%$ of inhibition at $200 \mu \mathrm{g} / \mathrm{mL}$ phenolic. These results demonstrated that isolated phenolic compounds from $P$. densiflora root could be expected to use as a functional cosmetic materials.
\end{abstract}

Keywords Activity $\cdot$ Beauty food $\cdot$ Extracts $\cdot$ Pinus densiflora root

Young-Je Cho $(\bowtie)$

E-mail: yjcho@knu.ac.kr

${ }^{1}$ School of Food science \& Biotechnology/Food \& Bio-Industry Research Institute, Kyungpook National University, 80 University Street, Bukgu, Daegu 41566, Republic of Korea

${ }^{2}$ School of Culinary Art and Baking technology, Dongju College University, Busan 49318, Republic of Korea

${ }^{3}$ Department of Food Science and Technology, Pukyong National University, Busan 48513, Republic of Korea

This is an Open Access article distributed under the terms of the Creative Commons Attribution Non-Commercial License (http://creativecommons. org/licenses/by-nc/3.0/) which permits unrestricted non-commercial use, distribution, and reproduction in any medium, provided the original work is properly cited.

\section{서 론}

오늘날 외모는 현대인들에게 있어서 개인이 가지고 있는 이미 지를 대표하는 중요한 요소이기 때문에 피부 관리에 대한 일반 인의 관심도가 높아지고 있다(Kim과 Yoo 2005; Lee 등, 2009). 최근에는 여성뿐 만 아니라 남성들에게도 피부 관리가 중요시 되고 있으며, 관리방법도 기본적인 화장품 사용을 비롯해 기능 성화장품, 팩이나 마사지를 통한 관리, 피부과에서의 전문적인 시술 등으로 다양화 되고 있다(Kim과 Park 2009). 피부는 조직 학적으로 표피, 진피, 피하지방의 3층으로 구성되어 있는데, 표 피는 이 중 가장 외부에 존재함으로써 피부 노화의 측면에서 가장 중요한 역할을 하며 이에 따라 피부 미용 분야에서도 가 장 집중적인 연구의 대상이 되고 있다(Rotts 1997). 표피는 연 령, 성별, 지엽적 부위, 지속적인 환경자극, 스트레스의 증가 등 의 외부자극 누적으로 인해 그 기능이나 구조에도 변화를 일으 키게 되며, 이러한 변화를 통해서 피부염증, 노화 등의 반응이 진행되고 피부 보호막으로서의 기능이 저하된다(Elias 1983; Feingold 1997). 여기에서 말하는 각질층은 피부의 수분을 보호 하고, 전해질의 소실을 억제하는 장벽의 역할로 인해 표피의 건 조를 막고, 표피가 정상적으로 체내의 생화학적 대사를 할 수 있는 환경을 제공한다. 그리고 외부의 물리적, 화학적 손상으로 부터 인체를 보호하고, bacteria, fungi, virus 등이 피부로 침범 하는 것을 방지하는 역할을 한다(Lee 등, 1995). 피부 표면은 자외선 노출과 같은 산화적 스트레스로 인해 활성산소가 과잉 생성된다. 특히 활성 산소종 중 $\mathrm{O}_{2}^{-}, \mathrm{OH}$ 는 피부 노화에 있어 서 매우 중요한 영향을 미치는데, 이러한 활성 산소는 피부 항 산화제 파괴, 피부 단백질의 산화, DNA 산화를 일으키고, 결합 조직 성분인 콜라겐, 히아루론산 등의 사슬 절단 및 비정상적 인 교차결합에 의한 염증, 주름, 멜라닌 생성 과정, 등에 참여 하여 피부 노화를 가속화시킨다(Joung 2010). 이에 건강에 대한 
관심이 높아지면서 피부를 유지, 관리하기 위한 화장품의 연구 가 활발히 이루어지고 있으며, 특히 식물계에 널리 분포되어 있 는 각종 생약과 식용식물로부터 추출한 페놀화합물은 안전하고 항산화 효과가 뛰어나서 천연 항산화제의 중요성이 부각되어 개 발 및 연구가 활발히 진행되고 있다(Halliwell과 Gutteridge 1990; Ramarathnam 등, 1995).

침엽수의 대표적인 소나무(Pinus densiflora Sieb. et Zucc.)는 소나무과(Pinaceae)에 속하는 상록교목으로 한국, 일본, 만주 등 에 자생하고 있으며, 국내 어느 지역에서나 널리 자라고 있는 사철 푸른나무이다(Oh 등, $1997 \mathrm{a} ; \mathrm{b})$. 예로부터 소나무의 잎, 솔 방울, 꽃가루, 송진, 껍질, 뿌리 등 모든 부위가 구황식물로 이 용되었으며 $(\operatorname{Lim}$ 등, 2002), 솔잎의 성분으로는 $\alpha$-oinine, $\beta$ pinene, camphene 등의 정유성분, ercetin, kaempferol 등의 flavonoid류, 수지 등이 함유되어 있다. 쉽게 채취할 수 있는 솔 잎은 민간요법 또는 한방에서 체내조직에서의 산화, 피부질환, 중풍을 예방하고(Boo 등, 1994), 간장질환, 위장질환, 신경계 질 환 등에 대한 효과와 동맥경화증, 고혈압, 당뇨병과 같은 노화 관련 질환을 예방하는 효능이 있는 것으로 알려져 있으며(Lee 등, 1996; Kim 등, 1997; Oh 등, 1998), 소나무 뿌리(동송근) 에 대한 건강기능식품 생리활성 연구 등이 보고되어 있다(Lee 등, 2016).

따라서 본 연구에서는 소나무 뿌리(동송근)로부터 phenolic compounds를 추출하여 미백, 주름개선, 수렴효과 및 항염증 등 의 미용식품활성에 대한 기능성을 검정하고, 기능성 소재로의 활용가능성을 알아보고자 하였다.

\section{재료 및 방법}

\section{실험재료}

본 연구에서 사용된 동송근은 시중 한약재상에서 판매하는 건 조품을 2016년에 구입하여 $40 \mathrm{mesh}$ 로 분쇄한 후 $4{ }^{\circ} \mathrm{C}$ 에서 냉장 보관하면서 시료로 사용하였다.

\section{동송근 추출물의 제조}

미용식품활성 측정을 위한 시료 추출은 전보(Lee 등, 2016)에 서 밝힌 바와 같이 water, ethanol 추출물 모두 건조된 동송근 분말 $1 \mathrm{~g}$ 을 증류수 $100 \mathrm{~mL}$ 와 $70 \%$ ethanol $100 \mathrm{~mL}$ 에 각각 첨 가하여 24시간 동안 shaking incubator에서 교반 추출하였다. 각 추출물은 Whatman No. 1 filter paper (Whatman Inc, piscataway, $\mathrm{NJ}, \mathrm{USA}$ )로 여과한 후 필요에 따라 rotary vacuum evaporator (Eyela NE, Tokyo, Japan)에서 농축하여 시료로 사용하였다.

\section{Total phenolic 정량}

Total phenolic 정량은 추출물 $1 \mathrm{~mL}$ 에 $95 \%$ ethanol $1 \mathrm{~mL}$ 와 증 류수 $5 \mathrm{~mL}$ 를 첨가하고 $1 \mathrm{~N}$ Folin-ciocalteu reagent $0.5 \mathrm{~mL}$ 를 잘 섞어 5 분간 방치한 후 $\mathrm{Na}_{2} \mathrm{CO}_{2} 1 \mathrm{~mL}$ 를 가하여 흡광도 725 $\mathrm{nm}$ 에서 1 시간 이내에 측정하여 gallic acid를 이용한 표준곡선 으로부터 양을 환산하였다(Folin과 Denis 1912).

\section{Tyrosinase 저해효과 측정}

Tyrosinase 저해효과 측정은 Vincent와 Hearing의 방법(1987)에
준하여 측정하였다. 반응구는 $0.1 \mathrm{M}$ sodium phosphate buffer (pH 6.8) $2.3 \mathrm{~mL}$ 와 $1.5 \mathrm{mM}$ L-tyrosine 기질 $0.4 \mathrm{~mL}$, mushroom tyrosinase (Sigma-Aldrich Co., Louis, MO, USA, $250 \mathrm{U} / \mathrm{mL}$ ) $0.1 \mathrm{~mL}$ 와 시료 $0.2 \mathrm{~mL}$ 를 넣고 대조구에는 시료 대신 증류수를 $0.2 \mathrm{~mL}$ 를 첨가하여 $37^{\circ} \mathrm{C}$ 에서 20 분간 반응시켜 흡광도 $475 \mathrm{~nm}$ 에서 측정하였다. 저해율(\%)은 (1-시료의 absorbance/대조구의 absorbance) $\times 100$ 으로 계산하였다.

\section{Elastase, collagenase 저해효과 측정}

Elastase 저해효과 측정은 Kraunsoe 등의 방법(1996)에 준하여 측정하였다. 반응구는 $0.2 \mathrm{M}$ Tris- $\mathrm{HCl}$ buffer $(\mathrm{pH} 8.0) 1 \mathrm{~mL}$ 에 $0.8 \mathrm{mM}$ N-succinyl-(Ala) $)_{3}-\rho$-nitroanilide 기질 $0.1 \mathrm{~mL}, 1.0 \mathrm{U} / \mathrm{mL}$ porcine pancreatice elastase (Sigma-Aldrich Co.) 효소 0.1 $\mathrm{mL}$ 와 시료 $0.1 \mathrm{~mL}$ 를 넣고 대조구에는 시료 대신 증류수 0.1 $\mathrm{mL}$ 를 첨가하여 $37^{\circ} \mathrm{C}$ 에서 20 분간 반응시켜 $\rho$-nitroaniline 생성 량을 흡광도 $410 \mathrm{~nm}$ 에서 측정하였다. Collagenase 저해효과 측 정은 Wunsch와 Heidrich의 방법(1963)에 준하여 측정하였다. 반 응구는 $0.1 \mathrm{M}$ Tris- $\mathrm{HCl}$ buffer $(\mathrm{pH} 7.5)$ 에 $4 \mathrm{mM} \mathrm{CaCl} 2$ 를 첨 가하여, 4-phenylazobenzyl oxycarbonyl-Pro-Leu-Gly-Pro-D-Arg $(0.3 \mathrm{mg} / \mathrm{mL})$ 를 녹인 기질 $0.25 \mathrm{~mL}$ 및 시료 $0.1 \mathrm{~mL}$ 의 혼합액에 $0.2 \mathrm{mg} / \mathrm{mL}$ collagenase (Sigma-Aldrich Co.) $0.15 \mathrm{~mL}$ 를 첨가하 였으며, 대조구에는 시료 대신 증류수 $0.1 \mathrm{~mL}$ 을 첨가하여 실온 에서 20 분간 방치한 후 $6 \%$ citric acid $0.5 \mathrm{~mL}$ 를 넣어 반응을 정지 시킨 후, ethyl acetate $2 \mathrm{~mL}$ 을 첨가하여 $320 \mathrm{~nm}$ 에서 흡광 도를 측정하였다. 저해율 $(\%)$ 은 (1-시료의 absorbance/대조구의 absorbance) $\times 100$ 으로 계산하였다.

\section{수렴 효과 측정}

Astringent 활성은 Lee 등의 방법(2002)에 준하여 측정하였다. 피부 단백질과 유사한 혈액 단백질(hemoglobin)을 사용하여, 원 심분리 용기에 각각의 시료와 헤모글로빈 용액을 $1: 1$ 로 넣어서 진탕 혼합한 다음 $2,000 \mathrm{rpm}$ 에서 원심분리 후 $576 \mathrm{~nm}$ 에서 흡광 도를 측정하였다. 대조구는 시료 대신 증류수를 넣어 반응시켰 다. 저해율 $(\%)$ 은 (1-시료의 absorbance/대조구의 absorbance) $\times$ 100 으로 계산하였다.

\section{Hyaluronidase (HAase) 저해효과 측정}

Hyaluronidase (HAase) 저해효과 측정은 Dorfman와 Ott의 방법 (1948)에 준하여 측정하였다. 반응구는 시료 $0.5 \mathrm{~mL}$ 에 $20 \mathrm{mM}$ sodium phosphate buffer ( $\mathrm{pH}$ 6.9)에 녹인 HAase $(1,000 \mathrm{U} /$ $\mathrm{mL}) 0.5 \mathrm{~mL}$ 을 혼합하여 $38^{\circ} \mathrm{C}$ 에서 5 분간 반응시키고 $0.3 \mathrm{M}$ phosphate buffer $(\mathrm{pH} 5.3)$ 에 녹인 기질 $(4 \mathrm{mg} / \mathrm{mL}) 0.5 \mathrm{~mL}$ 을 넣어 다시 $38^{\circ} \mathrm{C}$ 에서 45 분간 반응시킨 후 $0.04 \mathrm{M}$ acetate buffer $(\mathrm{pH} 3.75)$ 에 녹인 알부민용액 $5 \mathrm{~mL}$ 을 첨가한 후 5 분간 방치하 고 $600 \mathrm{~nm}$ 에서 투과율을 측정하였다. 대조구는 시료 대신 증류 수 $0.5 \mathrm{~mL}$ 를 넣어 반응시켰다. 저해율 $(\%)$ 은 (1-시료의 투과율/ 대조구의 투과율) $\times 100$ 으로 계산하였다.

\section{통계처리}

모든 실험은 3 회 이상 반복 측정하였고 자료의 통계처리는 SPSS 23 for windows (Statistical Package for Social Science, Chicago, IL, USA)를 이용하여 평균 \pm 표준편차 (mean \pm standard 
deviation)로 표시하였고 분산분석 Duncan's multiple range test one-way ANOVA를 실시하여 시료간의 유의차를 $p<0.05$ 수준 으로 비교 분석하였다.

\section{결과 및 고찰}

\section{동송근 추출물의 tyrosinase 저해효과}

Tyrosinase는 L-tyrosine과 페놀류를 산소에 의한 산화반응을 촉 매하는 효소로서, L-tyrosine에 작용해 3,4-dihydroxyp-henylalanine 이 되고 이를 거쳐 L-dopaquinone으로 전환되어 melanin 형성 에 관여하는 최종단계의 반응을 촉진하는 key enzyme으로 작 용한다. Tyrosinase는 최종 melanin 생합성 과정의 중요한 역할 을 하는 enzyme이므로 tyrosinase 억제제는 피부의 melanin 색 소생성을 조절할 수 있는 물질로 사용할 수 있다(Laskin과 Piccinini 1986). 본 실험에서는 melanin 형성에 관여하는 enzyme인 tyrosinase를 이용하여 저해효과를 측정한 결과 Fig. 1 에서와 같이 동송근 water 추출물 $50-200 \mu \mathrm{g} / \mathrm{mL}$ phenolics 농 도에서 14.8-22.3\%의 tyrosinase 저해효과를 나타내었으며, $449.24 \mu \mathrm{g} / \mathrm{mL}$ 의 $\mathrm{EC}_{50}$ 값을 나타내었다. Ethanol 추출물에서는 $50-200 \mu \mathrm{g} / \mathrm{mL}$ phenolics의 농도에서 91.8-97.7\%로 매우 높은 저해효과와 $102.35 \mu \mathrm{g} / \mathrm{mL}$ 의 $\mathrm{EC}_{50}$ 값을 나타내었다. 대조구로 사 용된 kojic acid는 35.2-77.0\%의 저해효과를 나타내었으며, Kim 등(2011)이 한약재 추출물을 $1.0 \mathrm{mg} / \mathrm{mL}$ phenolics 농도로 처리 하여 tyrosinase 저해효과를 측정한 결과 $34 \%$ 의 저해효과를 나 타낸 것과 비교하였을 때 동송근 추출물이 미백제로 시판 중인 kojic acid보다 더 높은 tyrosinase 저해효과를 나타내는 것을 확 인할 수 있었다. 따라서 미백제와 같이 mushroom tyrosinase에 직접적인 저해효과가 있는 미백 화장료로 활용될 수 있다고 판 단되었다.

\section{동송근 추출물의 elastase, collagenase 저해효과}

Elastin은 진피 내 피부 탄력을 유지하는데 중요한 기질 단백질 이며, elastase는 elastin을 분해하는 효소이다. 체내의 elastin을 분해하는 백혈구 과립 enzyme 중의 하나로, 이상 조직에서는

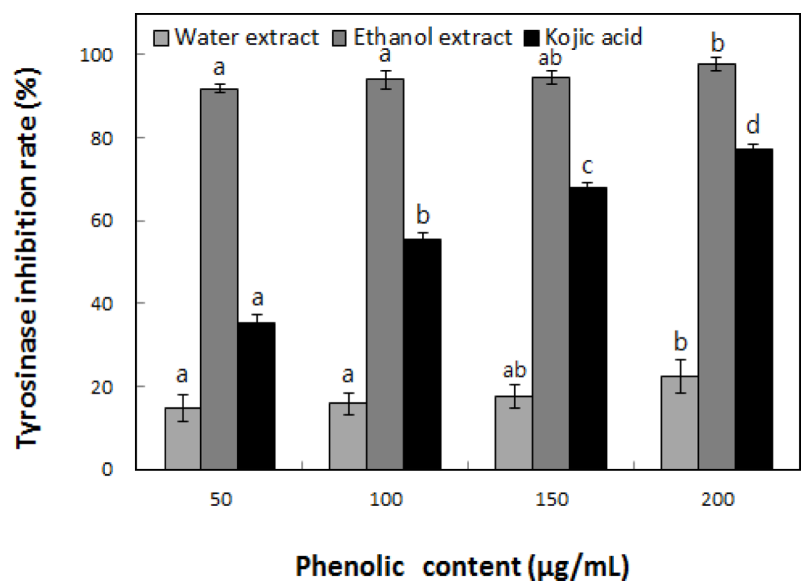

Fig. 1 Inhibitory activity of water and ethanol extracts from $P$. densiflora root on tyrosinase. Means with different superscript letters are significantly different at $p<0.05$ by Duncan's multiple range tests

elastase의 활성이 매우 높아져 피부 주름을 유발하고 탄력성 손 실을 일으키게 된다(Dewitt 등, 1981). 그러므로 피부개선제로 서 ursolic acid, epigallocatechin gallate (EGCG) 등의 elastase 저해제는 피부 주름을 완화하는 작용을 나타낸다. 이러한 피부 주름 생성과 관련된 enzyme인 elastase 저해효과를 측정한 결과 Fig. 2-A에서와 같이 동송근 water 추출물에서는 elastase에 대 한 저해효과가 나타나지 않았으며, ethanol 추출물 $50-200 \mu \mathrm{g} /$ $\mathrm{mL}$ phenolic 농도에서 28.5-61.6\%의 elastase 저해효과와 $162.34 \mu \mathrm{g} / \mathrm{mL}$ 의 $\mathrm{EC}_{50}$ 값을 나타내었다. Kwak 등(2005)은 약용 식물로 elastase 저해효과를 측정한 결과 대부분의 약용식물 추 출물 $1.0 \mathrm{mg} / \mathrm{mL}$ 농도에서 $30 \%$ 미만의 미미한 저해효과를 나 타내었으며, $\mathrm{Kim}$ 등(2004)은 한약재 복합 추출물 $1.0 \mathrm{mg} / \mathrm{mL}$ 농도에서 $64 \%$ 이상의 저해 활성을 나타내었다고 보고하여 동 송근 ethanol 추출물의 저해효과가 우수한 것을 알 수 있었다. 녹차에 함유된 polyphenol의 일종으로 시중화장품에 주름억제를 위한 agent로 사용되는 것으로 알려진 $\mathrm{EGCG}$ 와 동송근 ethanol 추출물의 elastase 저해효과를 비교 하였을 때 동송근 추출물이
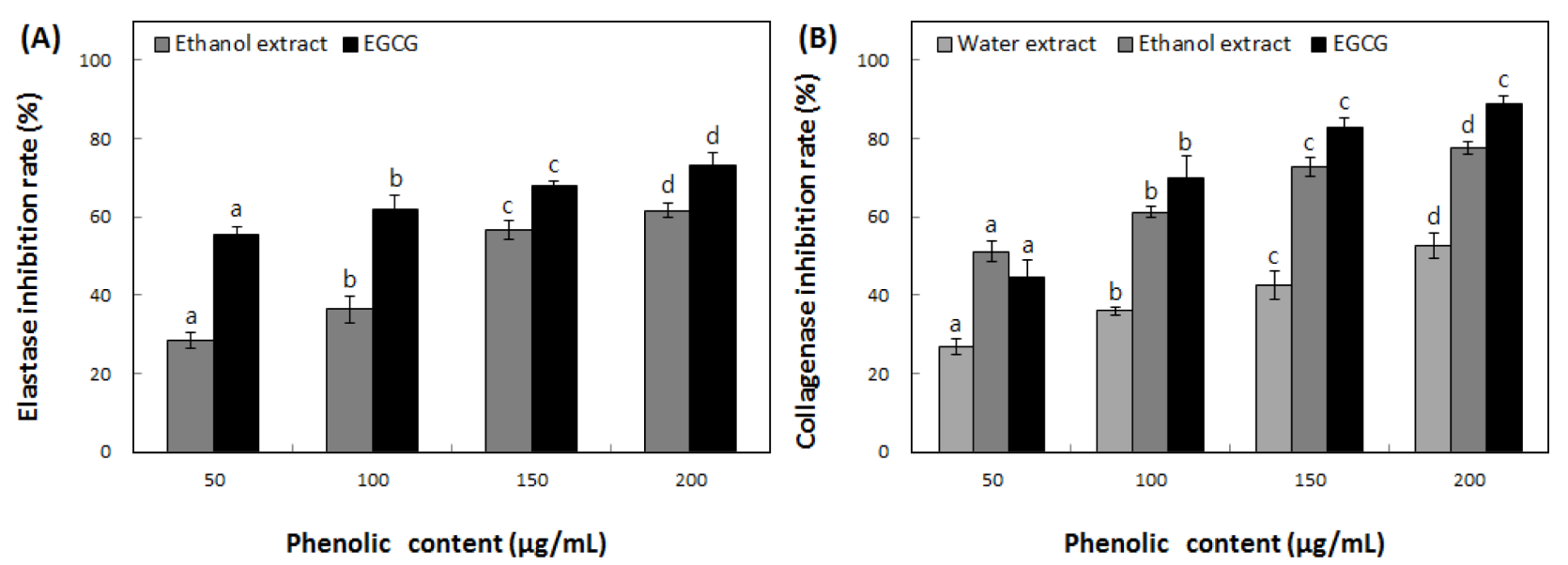

Fig. 2 Inhibitory activity of water and ethanol extracts from $P$. densiflora root on elastase (A), collagenase (B). Water extract has not shown activity on elastase. Means with different superscript letters are significantly different at $p<0.05$ by Duncan's multiple range tests 


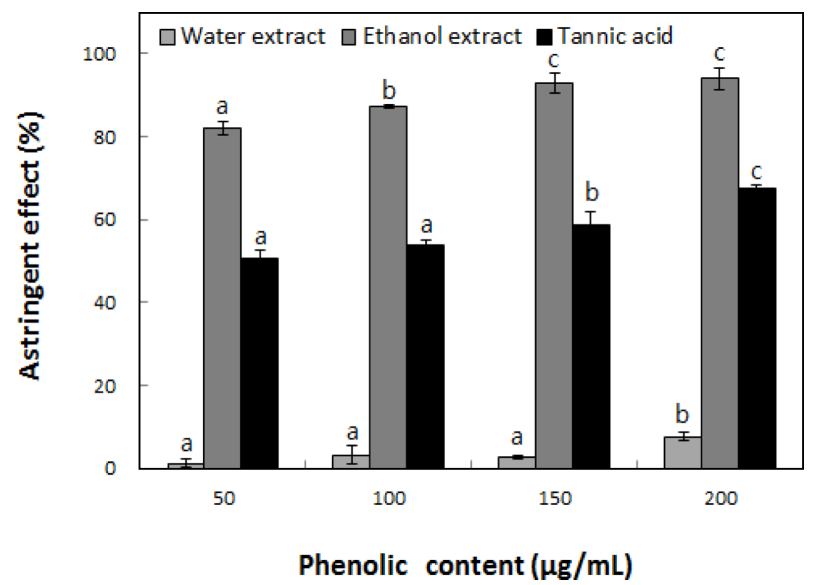

Fig. 3 Astringent effect of water and ethanol extracts from $P$. densiflora root. Means with different superscript letters are significantly different at $p<0.05$ by Duncan's multiple range tests

상대적으로 다소 낮은 저해효과를 나타내었으나 처리한 phenolic 농도에 따라 농도의존적으로 저해효과가 증가하는 것을 확인할 수 있었으며, 동송근 추출물도 EGCG와 같이 elastase 저해효과 가 있다는 것을 확인하였다. 피부의 fibroblast에서 생성되는 collagen은 extracellular matrix의 주요 구성성분으로 견고한 3중 나선구조를 가지고 있는 단백질이다. 뼈와 피부의 진피(dermis) 에 높은 함량으로 분포되어 있는 collagen은 피부, 건(tendon), 뼈 및 치아의 유기 물질의 대부분을 형성한다. Collagen의 주된 기능으로는 피부의 구조적 견고함, 세포의 접착, 세포 분할과 분화, 결합조직의 저항력과 조직의 결합력을 유도 하는 역할을 담당하고 있다(Jeroma 등, 1998). 이러한 collagen은 자외선에 의한 광노화에 의해서 감소하게 되며, 또한 단백질 분해효소인 collagenase에 의해 분해되어 피부의 구조적 견고함을 유지하고 있는 다발성 나선구조를 무너뜨려 주름을 발생시킨다(Grant과 Alburn 1959; Demina과 Lysenko 1996). Collagen을 분해하는 enzyme인 collagenase를 이용하여 저해효과를 측정한 결과 Fig. $2 \mathrm{~B}$ 에서와 같이 동송근 water 추출물 $50-200 \mu \mathrm{g} / \mathrm{mL}$ phenolics 농도에서 26.8-52.6\%의 저해효과를 나타내었으며, $\mathrm{EC}_{50}$ 값의 경 우 $190.26 \mu \mathrm{g} / \mathrm{mL}$ 로 확인되었다. Ethanol 추출물에서는 51.0$77.7 \%$ 의 저해효과를 나타내었고, $128.78 \mu \mathrm{g} / \mathrm{mL}$ 의 $\mathrm{EC}_{50}$ 값을 나 타내어 추출물 모두 농도의존적으로 collagenase 저해효과가 증 가하는 양상을 보여주었다. Lee 등(2004)은 유백피 추출물로 collagenase 저해효과를 측정한 결과 $100 \mathrm{ppm}$ 에서 $27.6 \%$ 의 저 해효과를 나타내었으며, Barrantes과 Guinea(2003)의 알로에 추 출물 경우 $37.1 \%$ 를 나타내었다고 보고한 것과 비교하였을 때 동송근 추출물의 효과가 매우 우수한 것으로 판단되었다. 따라 서 동송근 추출물은 피부 탄력을 유지하는데 중요한 단백질인 elastin과 collagen을 분해하여 주름 유발에 영향을 미치는 enzyme인 elastase, collagenase를 억제하여 피부 주름개선 효과 에 긍정적인 효과를 미치는 것으로 확인되었다.

\section{동송근 추출물의 수렴 효과}

수렴작용(astringent)은 동물의 근육에 구성되어 있는 단백질인 myosin, actin, myoglobin과 혈액에 존재하는 색소 단백질인

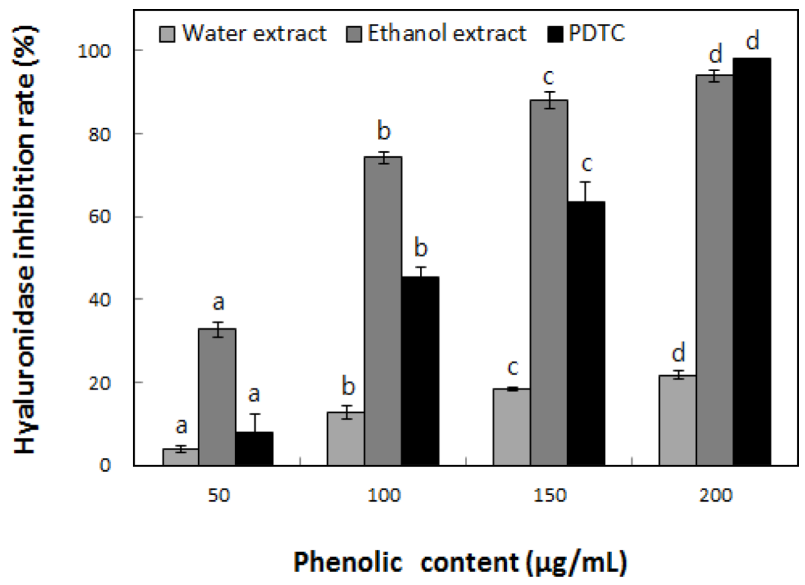

Fig. 4 Inhibitory activity of water and ethanol extracts from $P$. densiflora root on hyaluronidase. Means with different superscript letters are significantly different at $p<0.05$ by Duncan's multiple range tests

hemoglobin과 같은 피부 단백질이 고분자 phenolic compounds 와 가교결합을 형성하게 되어 피부가 수축되는 현상을 말한다. 이러한 수렴작용은 피부와 점막의 표면에 난용성의 피막을 형 성하거나 피부조직을 조밀하게 하여 세포막으로의 투과성을 감 소시키는 역할을 한다(Tsuji 2001). 피부 단백질인 hemoglobin 을 이용하여 수렴 효과를 측정한 결과 Fig. 3에서와 같이 water 추출물에서는 1.2-7.6\%로 다소 낮은 수렴 효과와 $1310.62 \mu \mathrm{g} /$ $\mathrm{mL}$ 의 $\mathrm{EC}_{50}$ 값을 나타내었으며, ethanol 추출물에서는 $50 \mu \mathrm{g} / \mathrm{mL}$ phenolic 농도의 저농도에서도 $81.9 \%$ 와 $106.43 \mu \mathrm{g} / \mathrm{mL}$ 의 $\mathrm{EC}_{50}$ 값으로 높은 수렴 효과를 나타내어 positive control로 사용한 tannic acid의 수렴 효과인 50.7-67.3\%에 비해 매우 우수한 효 과를 나타내었다. 이는 Lee 등(2002)의 함초 추출물이 $50 \%$ ethanol 및 acetone 추출물에서 $30 \%$ 의 수렴 효과를 나타내었다 고 보고한 것과 비교하였을 때 동송근 ethanol 추출물의 수렴 효과가 우수하다는 것을 확인할 수 있었고, 피부 단백질인 hemoglobin을 수축하여 수렴작용에 효과가 있다고 판단되어 모 공 축소효과를 활용한 기능성 화장품 원료로써 활용 가능성이 기대되었다.

\section{동송근 추출물의 hyaluronidase (HAase) 저해효과}

염증반응은 자외선과 같은 외부자극에 의해서 일어나는 생체조 직의 방어반응의 한 종류로서 활성화된 면역세포에 의해 일어 나는 일련의 면역반응이다. Epidermis와 dermis에 있어서 주요 한 세포외 metrix인 hyaluronic acid (HA)는 glucuronic acid와 glucosamine이 반복해서 연결된 고분자의 점액성 mucopolysaccharide이다. 고분자 $\mathrm{HA}$ 는 염증 형성의 중요 요소인 macrophage의 phagocytic ability를 저해시키지만, 저분자 HA는 inflammation, fibrosism collagen deposition을 증가시킨다고 알 려져 있다. 따라서 $\mathrm{HA}$ 분해효소인 HAase의 활성을 억제함으 로서 $\mathrm{HA}$ 의 고분자 형태를 유지시켜 항염증 효과를 기대할 수 있다(Ghosh 1994; Cho과 An 2008). 염증 형성의 중요 요소인 HAase 저해효과를 측정한 결과 Fig. 4에서와 같이 water 추출 물에서는 $50-200 \mu \mathrm{g} / \mathrm{mL}$ phenolic 농도에서 $3.8-21.7 \%$ 의 저해효 과를 나타내었으며, $\mathrm{EC}_{50}$ 값은 $460.41 \mu \mathrm{g} / \mathrm{mL}$ 으로 나타내었다. 
Ethanol 추출물에서는 $50-200 \mu \mathrm{g} / \mathrm{mL}$ phenolic 농도에서 32.8$94.0 \%$ 의 저해효과와 $106.39 \mu \mathrm{g} / \mathrm{mL}$ 의 $\mathrm{EC}_{50}$ 값을 나타내어 100 $200 \mu \mathrm{g} / \mathrm{mL}$ 의 고농도에서는 매우 높은 HAase 저해효과를 보여

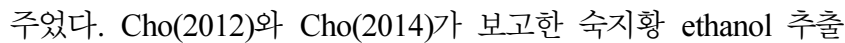
물과 미세분쇄 감국 ethanol 추출물에서 각각 $5.1,35.1 \%$ 의 저 해효과를 나타내었다고 보고한 것과 비교하였을 때 동송근 ethanol 추출물의 HAase 저해효과가 우수하다는 것을 확인할 수 있었으며, 염증 유발 요소인 HAase 저해로 인한 항염증, 아토 피 억제효과를 활용하는 제품에 적용할 수 있을 것이라 판단되 었다.

\section{초 록}

소나무 뿌리(동송근)로부터 phenolic compounds를 추출 후 미 용식품활성을 검정하여 기능성 소재로 활용가능성을 살펴보았 다. 동송근에 함유된 페놀성 물질의 tyrosinase 저해효과를 측정 한 결과 $50 \mu \mathrm{g} / \mathrm{mL}$ phenolics 농도에서 ethanol 추출물이 $92 \%$ 의 tyrosinase 저해효과를 나타내었다. Elastase와 collagenase 저 해효과를 측정한 결과 $200 \mu \mathrm{g} / \mathrm{mL}$ phenolics 농도에서 ethanol 추출물이 각각 $61,78 \%$ 의 높은 저해력을 나타내어 주름개선효 과가 높았다. 수렴효과는 $50 \mu \mathrm{g} / \mathrm{mL}$ phenolics의 저농도 ethanol 추출물에서 $82 \%$ 의 저해효과를 나타내었다. 염증억제효과를 나 타내는 hyaluronidase 저해효과를 측정한 결과 $100-200 \mu \mathrm{g} / \mathrm{mL}$ phenolic 농도의 ethanol 추출물에서 $74-94 \%$ 의 매우 높은 염증 억제효과를 나타내었다. 이러한 결과로 보아 동송근 추출물이 미용식품활성 또는 기능성 소재로서 활용이 가능할 것으로 판 단되었다.

\section{Keywords 동송근 - 미용식품 - 추출물 - 활성}

\section{References}

Barrantes E, Guinea M (2003) Inhibition of collagenase and metalloproteinases by aloins and aloe gel. Life Sci 72: 843-850

Boo YC, Jean CO, Oh JY (1994) Isolation of 4-hydroxy-5-methyl-3[2H]furanone from pine needles as an antioxidative principle. J Korean Soc Agric Chem Biotechnol 37: 310-314

Cho YJ (2012) Charactrization of biological activities of Rehmannia glutinosa extracts. Journal of Life Science 22: 943-949

Cho YJ (2014) Biological activity of extracts from Chrysanthemum incidicum Linne by ultrafine grinding. J Korean Soc Food Sci Nutr 43: 110-117

Cho YJ, AN BJ (2008) Anti-inflammatory effect of extracts from Cheongmoknosang (Morus alba L.) in Lipopolysaccharide stimulated Raw cells. J Kor Soc Appl Biol Chem 51: 44-48

Demina NS, Lysenko SV (1996) Collagenolytic enzymes synthesized by microorganisms. Mikrobiologiia 65: 293-304

Dewitt DL, Rollins TE, Day JS, Gauger JA, Smith WL (1981) Orientation of the active site and antigenic determinants of prostaglandin endoperoxide of synthase in the endoplasmic reticulum. J Biol Chem 256: 10375 10382

Dorfman A, Ott ML (1948) A turbidimetric method for the assay of hyaluronidase. Journal of biological chemistry 172: 367-375

Elias PM (1983) Epidermal lipids, barrier function, and desquamation. Journal of Invest Dermatol 80: 44-49

Feingold KR (1997) Permeability barrier homeostasis: its biochemical basis and regulation. Cosmet Toilet 112: 49-59

Folin O, Denis W (1912) On phosphotungstic-phosphomolybdic compounds as colcor reagents. J Biol Chem 12: 239-243

Ghosh P (1994) The role of hyaluronic acid (hyaluronan) in health and disease: interactions with cells, cartilage and components of synovial fluid. Clin Exp Rheumatol 12: 75-82

Grant NH, Alburn HE (1959) Studies on the collagenases of Clostridium histolyticum. Arch Biochem Biophys 82: 245-255

Halliwell B, Gutteridge JM (1990) Role of free radical and catalytic metal ions in human disease, an overview. Methods Enzymol 186: 1-85

Jeroma SP, Gabrielle L, Raul F (1998) Identification of collagen fibrils in scleroderma skin. J Invest Dermatol 90: 48-54

Joung KH (2010) Physicochemical characteristics of dasik using Scatteredflower ladybell(Adenophora remotiflora). Dissertation, Kongju National University

Kwak YJ, Lee DH, Kim NM, Lee JS (2005) Screening and extraction condition of anti-skin aging elastase inhibitor from medicinal plants. Kor J Med Crop Sci 3: 213-216

Kim IK, Shin SR, Chung JH, Youn KS, Kim KS (1997) Changes on the components of dongchimi added ginseng and pine needle. Korean $\mathrm{J}$ Food Sci Technol 9: 153-160

Kim MJ, Kim JY, Choi SW, Hong JT, Yoon KS (2004) Anti-wrinkle effect of safflower(Cathamus tinctotius) seed extract. J Kor Soc Cosmetic Sci 30: $15-22$

Kim MR, Hwang JH, Yun JK, Han KH, Do EJ, Lee JS, Lee EJ, Kim JB (2011) Antioxidation and anti-aging effect of mixed extract from Korean medicinal herbs. Kor J Herbology 26: 111-117

Kim SR, Yoo TS (2005) The relationships between the extent of women ${ }^{\circ}$ s skin care by clothing behavior and self-efficacy. J Kor Soc Cloth Ind 7: 413-418

Kim YS, Park JY (2009) The analysis on appearance management of male college students: focused on management of hair, skin, cosmetic surgery, fashion and body shape. Korean J Human Ecol 18: 259-273

Kraunsoe JAE, Claridge TDW, Lowe G (1996) Inhibition of human leukocyte and porcine pancreatic elastase by homologues of bovine pancreatic trypsin inhibitor. Biochemistry 35: 9090-9096

Laskin JD, Piccinini LA (1986) Tyrosinase isozyme heterogeneity in differentiating B-16/C3 melanoma. J Biol Chem 261: 16626-16635

Lee EH, Kim NH, Park MJ, Hong EJ, Park KT, An BJ, Ahn DH, Cho YJ (2016) Functional food activities of extracts from Pinus densiflora root. Korean J Food Preserv 23: 110-116

Lee JT, Jeong YS, An BJ (2002) Physiological activity of Salicornia herbacea and its application for cosmetic materials. Kor J Herbology 17: 51-60

Lee SH, Chung HS, Lew W (1995) Epidermal lipid homeostasis. Ann Dermatology 7: 99-111

Lee SH, Lee KO, Kim SO (2009) Effects of skin care on users' mental health and self-esteem. J Kor Soc Cosm 15: 155-167

Lee TW, Kim SN, Jee UK, Hwang SJ (2004) Anti-wrinkle effect of pressure sensitive adhesive hydrogel patches containing Ulmi cortex extract. J Kor Pharm Sci 34: 193-199

Lee YH, Shin YM, Cha SH, Choi YS, Lee SY (1996) Development of the health foods containing the extract from Pinus strobus leave. J Korean Soc Food Sci Nutr 25: 379-383

Lim YS, Bae MJ, Lee SH (2002) Antimicrobial effects of Pinus densiflora Sieb. et Zucc. ethanol extract on Listeria monocytogenes. J Korean Soc Food Sci Nutr 31: 333-337

Oh YA, Choi KH, Kim SD (1997a) Changes in enzymes activities and growth of lactic acid bacteria in pine needle added kimchi during fermentation. $\mathrm{J}$ Food Sci Technol 9: 75-84

Oh YA, Choi KH, Kim SD (1998) Changes in enzyme activities and population of lactic acid bacteria during the kimchi fermentation supplemented with water extract of pine needle. J Korean Soc Food Sci Nutr 27: 244-251

Oh YA, Sae KY, Kim SD (1997b) Quality of pine needle added kimchi. J Food Sci Technol 9: 51-56 
Ramarathnam N, Osawa T, Ochi H, Kawakishi S (1995) The contribution of plant food antioxidants to human health. Trends Food Science 6: 75-82

Rotts R (1997) Skin barrier: Principles of percutaneous absorption. Hans Schaefer; Thomas E. Redelmeier. Archives of dermatology 133: 924

Tsuji N, Moriwaki S, suzuki Y, Takema Y, Imokawa G (2001) The role of elastases secreted by fibroblasts in wrinkle formation: implication through selective inhibition of elastase activity. Photochem Photobiol 74:
283-290

Vincent J, Hearing JR (1987) Mammalian monophenol monooxygenase (tyrosinase): Purification, properties, and reactions catalyzed. Method Enzymol 142: 154-165

Wunsch E, Heidrich HG (1963) Zur quantitativen bestimmung der kollagenase. Hoppe-Seyler's Physiol chem 333: 149-151 